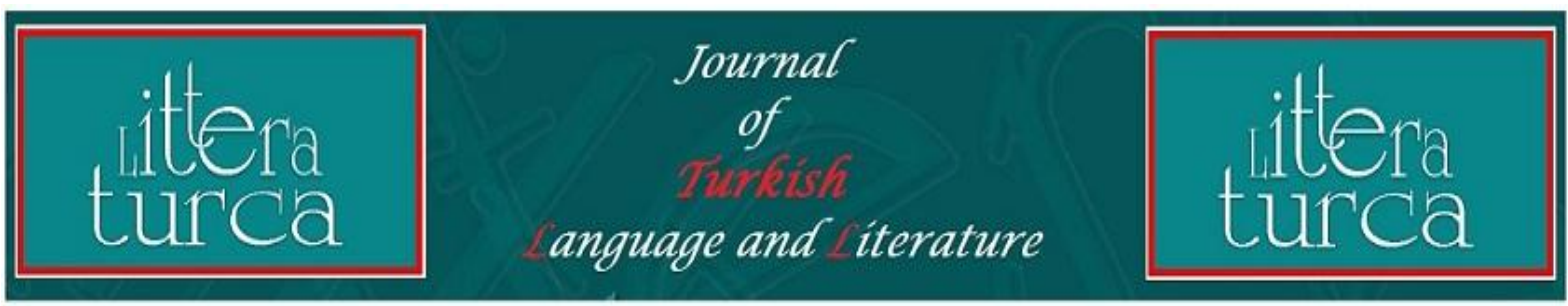

Geliş Tarihi/Received Date: 24.05.2019

Kabul Tarihi/Accepted Date: 31.07.2019

\title{
EBÜZZIYA TEVFIK'IN JEAN JACQUES ROUSSEAU TERCÜME-i HÂLi
}

\author{
Bekir OCAK ${ }^{1}$
}

ÖZET

XIX. asrın en bilindik simâlarından Ebüzziyâ Tevfik, dönem yazınının en üretken şahısları arasında yer almaktadır. Edebiyatımıza ve düşünce dünyamıza önemli katkılar sağlamış olan Ebüzziya, birçok yayın organı içerisinde yer almış ve yazılarıyla dönemine ışık tutmuştur. Batılılaşma gayreti gösteren Osmanlı'ya, Batı'ya yön veren birçok ismi tanıtmış ve onlar hakkında dikkate şayan eserler meydana getirmiştir. Ebüzziya Tevfik'in Latin harflerine aktardığımız bu metni ise Fransız düşünür ve yazarlarının en önemli isimlerinden biri olan Rousseau hakkındadır. Rousseau'nun hayatının kaleme alındığı bu metin, hem Tanzimat münevverinin yöneldiği kaynakları tespit etmek hem de Batılılaşma serüveninde izlenen yolu anlamak açısından önem teşkil itmektedir.

Anahtar Kelimeler: Ebüzziya Tevfik, Rousseau, Tanzimat.

\section{ABSTRACT}

Ebuzziyâ Tevfik, one of the most well-known intellectual of the 19th century, is among the most productive persons of the literature of his period. Ebuzziyâ who has made important contributions to our literature and world of thought, has been involved in many publications and has shed light on his period with his writings. He introduced many Western figures, led the Western world, to the Ottomans who in the Westernization effort and he gave the remarkable works about them. This text of Ebuzziya Tevfik's that we transliterated to Latin letters is about Rousseau, one of the most important names of French thinkers and writers. This thext in which Rousseau's life is written is important in the terms of both to identify the sources which are directed by Tanzimat intellectuals and to understand the path followed in Westernization adventure.

Keywrords: Ebüzziya Tevfik, Rousseau, Tanzimat.

\footnotetext{
${ }^{1}$ Atatürk Üniversitesi, Sosyal bilimler Enstitüsü Doktora Öğrencisi, ocakbekir21@gmail.com.
}

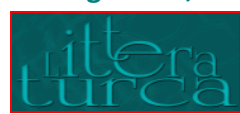

Journal of Turkish Language and Literature

Volume:5, Issue:3, Summer 2019, (471-487)

Doi Number: 10.20322/littera.530595 


\section{GiRiş}

XVIII. Asır dünya tarihi açısından Fransızlar için çok önemli bir dönüm noktası teşkil etmektedir. Fransız medeniyetinin hemen her alanda etkin olduğu bu dönemde Avrupa toplumları gözlerini Fransızlar üzerinden ayıramamışlardır. Dolayısıyla "Fransız dili yavaş yavaş diplomasi, felsefe, ilim ve sosyete dili olmuş ve Latincenin yerini almıştır." (Perin, 1946: 17)

Bu durumun tabiatı itibariyle bir tesadüf eseri meydana gelmediği bilinmektedir. Özellikle XVII. Asırdan sonra Sanayi İnkılabı ve kolonizasyon ile zenginleşen Fransızlar, maddi açıdan bir refah dönemi yaşamışlardır. iktisadi bakımdan oldukça zenginleşen Fransa'da bu zenginlik kültür sahasına da sıçramışır. 1789'da gerçekleşecek olan ihtilalin hazırlayıcısı işte XVII. asırdaki bu kültürel iklimden beslenmiştir.

1700'lü yılların başında doğan ve Fransız ihtilali'ne doğru giden yolun mihmandarları olan birçok Fransız mütefekkir yer almaktadır. Bunlardan bazıları Jean Jacques Rousseau (1712-1778), Voltaire (1694-1778), Montesquieu (1689-1755), d'Alembert (1717-1783), Diderot (1713-1784) gibi isimlerdir. Bu şahıslar, Fransa'nın yaşamış olduğu bu altın çağı sanatlarıyla ve düşünceleriyle daha değerli bir hale getirmişler ve aynı zamanda özellikle Avrupa toplumlarının istikametini belirlemişlerdir.

Bu çalışmamızda konumuzun temelini teşkil ettiğinden hemen üstte zikredilen isimler arasından Jean Jacques Rousseau'yu incelemeye çalıştık.

Kalemiyle sadece yaşadığı 18. asrı değil kendinden sonraki asırları da etkilemiş ve bu etkisi halihazırda süren dünya tarihindeki önemli isimlerden biri olan Jean Jacques Rousseau, 1712 yılının haziran ayında İsviçre'nin Cenevre kentinde dünyaya gelmiştir.

İsviçreli bir saatçi olan İsaac Rousseau (1672-1747) ve bir rahip kızı olan Suzanne Bernard'ın (1673-1712) çocukları olarak dünyaya gelen Jean Jacques Rousseau, annesini kendi doğumu sırasında kaybetmiştir. Bu hadiseyi itiraflar adlı eserinde şu cümlelerle anlatmıştır. "Annemde, kendini koruyabilmesi için faziletten de daha fazla bir şey vardi; babam da her şeyi bırakarak geldi. Ben bu dönüşün hazin mahsulü oldum. On ay sonra sakat ve hasta olarak doğuyordum. Sonra da annemin hayatına mal oldum. Böylece doğuşum felaketlerimin ilk numarası oldu." (Rousseau, 1991: 6)

Doğumu sırasında kaybettiği annesinden kalan romanlar Rousseau'nun okuma alışkanlığı kazanmasına vesile olmuştur. Bu alışkanlık, daha sonra küçük çocuğun merak etme ve öğrenme iştiyakının başlangııını oluşturmuştur. Ancak doğumundan itibaren öksüz olan Rousseau on yaşına eriştiğinde saatçi babasının şehrin itibar gören kişilerinden biri ile girdiği kavganın neticesinde şehri terk etmek zorunda kalması bu küçük çocuğun hayatının artık babasız devam edeceğini de göstermiştir. Bu hadisenin ardından genç Rousseau'nun hayatı gittikçe daha da zorlaşmıştır. (Simavi, 1931: 11)

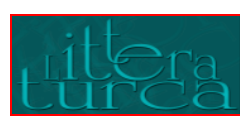

Journal of Turkish Language and Literature

Volume:5 Issue:3, Summer 2019, (471-487)

Doi Number: 10.20322/littera.530595 
Gençlik yıllarında birçok kez yer değiştirmek zorunda kalan Rousseau'yu yersiz ve yurtsuz olmak derinden etkilemiştir. Ebeveynlerinden uzak büyümek zorunda kalan bu Fransız gencin karakteri bu yoksunluklar neticesinde şekillenmiştir. Onun daha sonrasında ünlü bir düşünür olduğu dönemlerde de bu mizacın yansımaları girdiği polemiklerde de sezilmiştir. Dünya düşün tarihine adını yazdıran Roussseau, çağdaşları Voltaire, Diderot ve d’Alembert gibi Fransız Aydınlanmasının önde gelen düşünürleri ile yollarını ayırmış, dostane başlayan ilişkileri hem fikirsel hem kişisel sebeplerle Rousseau'nun ölümüne kadar fırtınalı bir seyir sürmüştür. (Orhan, 2013: 123)

Kaleme aldığı yapıtlarıyla ülkeler arası bir şöhrete ulaşan Rousseau'nun Türk toplumu tarafından tanınması Tanzimat Devrine denk gelmektedir. Dolayısıyla 18. Asrın önemli isimlerinden biri olan bu düşünürü Türk aydını 19. Asrın ortalarındaki değişim hareketinin önemli figürlerinden biri haline getirmiştir. Ziya Paşa (1825-1880), İbrahim Şinasi (1826-1871), Namık Kemal (1840-1888), Ahmet Mithat Efendi (1844-1912) ve Ebüziyya Tevfik (1849-1913) gibi yazarlar Rousseau'nun muhtelif eserlerini okumuş, Türkçeye çevirmiş ve çıkardıkları dergilerde yayınlamışlardır. (Orhan, 2013: 129)

$\mathrm{Bu}$ isimler arasında yer alan XIX. asır münevverlerinin en önemli simalarından biri olan Ebüzziya Tevfik, Tanzimat Fermanı'nın Gülhane'de okunmasından yaklaşık on sene sonra (1849) İstanbul'da dünyaya gelmiştir. Ebüzziya'nın içine doğduğu çağ, Osmanlı toplumu açısından oldukça çalkantılı bir dönemdir. Hasan Kâmil Efendi'nin oğlu olarak dünyaya gelen Ebüzziya Tevfik, ilk tahsiline Sultanahmet'te Cevri Kalfa Sıbyan Mektebi'nde başlamıştır. 1857' de babasının ölümü üzerine “peder- mande” denilen usule göre onun yerine aynı daireye memur olarak alınan Tevfik, on yedi yaşına kadar Maliye'nin çeşitli kalemlerinde çalışmıştır ve daha sonra buradan Şûra-yı Devlet ikinci sınıf mülkiye mülazımlı̆ı̆na getirilmiştir. (1868). (Ebüzziya, 1994: 374)

Gençlik yıllarında başlangıçta Arapça ve Farsça öğrenen daha sonra Fransızca, Almanca gibi dilleri de öğrenen Ebüzziya, Osmanlı toplumunda gazete ve mecmuaların öneminin gittikçe artmasıyla dönemin önemli yayınları olan Rûznâme-i Cerîde-i Havâdis ve Tasvîr-i Efkâr'da metinler yayımlamıştır. Basın dünyasına bir hayli ilgi duyan Ebüzziya Tevfik, ömrü boyunca birçok gazete ve mecmuanın içerisinde yer almış hatta bunların birçoğunun basımını da kendi üstlenmiştir. "Halkın uyanmasına ve kültür sahibi olmasına vesile teşkil edecek eserler basmak maksadıyla yayımcılığa başlayan Ebüzziya, özellikle Şinâsi ve Nâmık Kemal'in eserlerini basarak bunların düşüncelerinin geniş kitlelere ulaşmasını sağlamıştır." (Ebüzziya, 1994: 376, 377)

Matbaa, gazete, mecmua, hat ve süsleme gibi birçok alanda başarılı olan Tevfik, Batılılaşma yolunda Türk toplumunun kültürüne önemli katkılar sağlamıştır. Bu anlamda tercüme eserler, biyografik metinler, takvim ve almanaklar, antolojiler Tevfik'in kültür hayatımıza sunduğu ürünlerden sadece bazılarıdır.

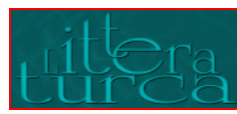

Journal of Turkish Language and Literature

Volume:5, Issue:3, Summer 2019, (471-487)

Doi Number: 10.20322/littera.530595 
Latin harflerine aktardığımız bu eser ise, Tanzimat münevverinin örnek aldığı ünlü Fransız düşünürü ve yazarı Rousseau'yu konu edinmektedir. Sözü geçen bu eser, Atatürk Üniversitesi Merkez Kütüphanesi'nin, Seyfettin Özege Kitaplığı'ndan tedarik edilmiş olup, 0114299 demirbaş, 6845 SÖ yer numarasına kayıtlıdır.

\section{EBÜZZIYA TEVFiK'iN JEAN JACQUES ROUSSEAU TERCÜME-i HÂLi}

Kitâbhâne-i Meşâhir-'Aded-i Kitâb: 11

Jan Jak Ruso

Ebû'z-Ziyâ Tevfîk

Birinci Tab"

Meclis-i Ma'ârifin Ruhsatıyla Tab' Olunmuştur

Kostantîniyye

1303

Matba'a-ı Ebû'z-Ziyâ

Her Hakkı Mahfûzdur. [1]

\section{JAN JAK RUSO}

Ruso'nun nâmı yâd edilince Volter'in², Volter'in ismi zikr olununca Ruso'nun hâtıra gelmemesi bu iki şahs-ı 'azîmü'l-kadrin ahvâl-i husûsiyyesini bilenlerce hemân nâ-kâbildir denebilir.

Volter'le Ruso onsekizinci 'asrın e'âzım-ı erkânından idiler. Şurası muhakkakdır ki her ikisi de ayrı ayrı mazhariyetde adamlar olduğu hâlde her ikisi de bir maksada hizmet etmişlerdir.

Volter her şeyden bahseder ve her bahşettiği şeyde muzafferiyeti ihrâz eylerdi. Ruso ise "bir 'ârifim ki zıddına gittim bu 'âlemin" kavlinin mâ-sadak müşahhası olmağla, yalnız istediği şeyden bahseder ve bahsettiği şeyler ekseriyet üzere mebâhis-i müte ârifenin hilâfına zuhur eylerdi.

${ }^{2}$ François Marie Arouet-Voltaire (1694-1778): Fransız filozof

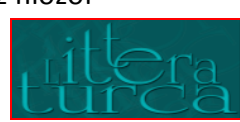

Journal of Turkish Language and Literature

Volume:5 Issue:3, Summer 2019, (471-487)

Doi Number: 10.20322/littera.530595 
Mesela, 'âlem fazl û 'irfân esâs-gîr olduğu zamândan³ [3] Jân Jâk Ruso 1712 senesi hazirânının 28'inci günü İsviçre Cumhûriyeti memâliğinden (Jenev) ${ }^{4}$ şehrinde tevellüd etmiştir. Pederi ekser hemşehrileri gibi sâ'atcilik san'atıyla meşgûl ve san 'atından ancak 'âilesini idâre edecek derecelerde merzûk bir adam idi. Ruso'nun evâ’il-i şebâbı derece-i fevka'l-'âdede olan kuvve-i hayâliyesiyle şerh eyleye geldiği birçok hikâye kitâblarını mütâla'a ile mürûr eylemiştir.

Roman okumak merâkı ber-taraf olduktan sonra (Plütarh'ın) ${ }^{5}$ âsâr-ı mütercimesini mütâla'aya hasr-ı evkât eyledi. Biraz Lâtinceden başka hiçbir şey istifâde etmediği leylî bir mektebden çıktıktan sonra mahkeme kitâbeti mülâzımlığına ve orada usûl-i sakk ile ülfet edememesi üzerine hakkâk çıraklığına verilmiş ve bu san'atda dahi tünd-hûlkda nâdirü'l-emsâl olan üstâdının gündeye kullandığı dayâğa tahammül edemediğinden (Ânsi) ${ }^{6}$ kasabasına firâr eylemiştir. Ansi'de Madam (Varens) ${ }^{7}$ [6] nâmında bir hâmiyyeye nail olmağla anın yanında bir zamân evlâd gibi yaşamış ve hatta Fransa üdebâ-yı hükemâsının âsâr-ı kalemiyyesiyle ülfetine mûmâ-ileyhânın teşvîkâtı sebeb olmuştur.

Ruso, bu târihte 17 yaşında olduğu hâlde hâmiyyesinin ilhâhı üzerine mezheb-i mâder-zâdı olan Protestanlıktan 'udûl ile Katolik âyînini kabûl itmiş ve bu tebdîl-i mezheb husûsu, ebeveyn ve akrabasının kendisinden nefretini ve bu nefret ise Ruso'nun inkılâbât gûnâ-gûn ile güzerân eden avân-ı hayâtında hiçbir sûretle teselliyet kabûl edemeyecek derecelerde küdûretini mûcib olmuştur. Madam Varens Jan Jak Ruso'ya, i'tikâdınca daha büyük bir lûtf itmiş olmak içün meslek-i ruhbâniyete dâhil olmağı teklif eylemiş ve Ruso ise ittihâz edeceği meslek hakkında henüz bir karar-ı kat'i vermemiş olmasından bu teklif üzerine ruhbâniyete mahrec olan bir mektebe girmiş ise de papazlığın kademe-i evvelîsine ayak basmadan mertebe-i kusvasına kadar medd-i nazar-ı tedkîk etmekle meslek-i ruhbâniyetin duzahiyâne bir takım ef'âline vâkıf olarak oradan da firâr ile tekrar hâmiyyesine ilticâ eylemiştir. [7]

\footnotetext{
${ }^{3}$ Çeviri metnin ilk sayfasının son cümlesi olan bu cümle metne sonradan eklenmiş hüviyeti vermektedir. Bu durumun anlaşıması açısından çevrilen metnin bahsi geçen kısmı aşağıdaki görselde verilmiştir. Bunun yanı sıra 3. sayfanın ardından gelen 4. ve 5. sayfaların metinde yer almadığı tespit edilmiş ve 3. sayfanın ardından 6. sayfadan devam edilmiştir.

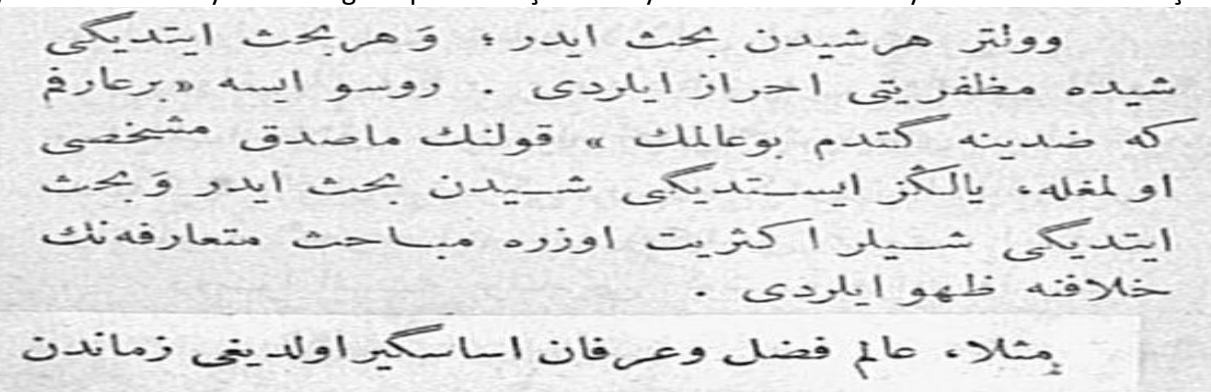

${ }^{4}$ Ville de Geneve: İsviçre'de bir şehir

${ }^{5}$ Lucius Mestrius Plutarchus: Plütarh milâdın 140'ıncı sâlinde vefât etmiş bir münşîdir ki Yunan ve Roma meşâhirinin vefeyâtını yazmıştır. (Yazarın dipnotu)

${ }^{6}$ Annecy: Fransa'nın güneydoğusunda yer alan bir yerleşke

${ }^{7}$ François-Louise de Warens (1699-1762): Rousseau'nun koruyuculuğunu yapan manevi annesi
}

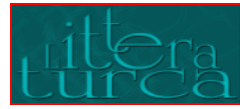

Journal of Turkish Language and Literature

Volume:5, Issue:3, Summer 2019, (471-487)

Doi Number: 10.20322/littera.530595 
Madam [Varens] Ruso'yu, bir vâlidenin evlâdına olan muhabbetine mümâsil bir muhabbetle sever idi. Bu cihetle mekteb-i ruhbâniyetten firârından dolayı münfa'il olduktan başka bu kerrede kendisini mûsîkî ta'limi içün Lyon'da bir mu'allime verdi. Ruso sinn-i şebâbetiyle mizâc-ı âteşîni mukteziyâtına ittibâ'dan kendini alamadığı ve ekser erbâb-ı hünerde vücûdu derkâr olan san'at ta'assubunu mûsîkî mu'alliminde ma'-ziyâde mevcûd bulduğu cihetle üstâdının evzâ'ını çekemeyerek Lyon'dan da savuştu. Fakat bu def'a Ansi'ye muvâsalatında Madam dö Varens'i bulamadığından melce siz ve hâmiyyesiz kalarak düçâr-ı sefâlet olacağını 'aklı kesmekle henüz tamamıyla ta'allüm etmediği mûsîkîyi istek edenlere ta'lîm târîkiyle te'mîn-i ma îşet eylemek içün (Loren'e) gitmeye karar verdi.

Bu tarihten i'tibâren Ruso mütemâdiyen mûsîkî dersi vererek kâh Nöşatel ${ }^{8}$, Sölor ve Paris'de ve kâh Madam dö

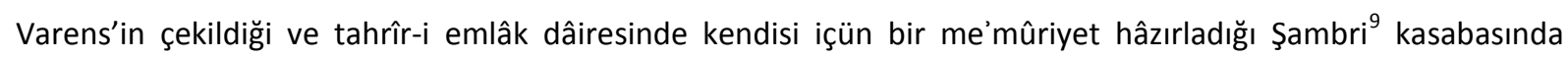
imrâr-ı evkât etmişdir. [8]

Biraz sonra büyük kilisenin mûsîkî mu'alliminden nota tertîbi dersi almak üzre (Bezanson'a) ${ }^{10}$ ve oradan dahi $\left(\right.$ Mabli) ${ }^{11}$ nâmında bir hâkimin çocuklarına lalalık etmek üzre Lyon'a ve nihâyet notaları erkâm ile tertîb içün icâd ettiği kâiidenin neşri maksadıyla Paris'e gitmiştir. Zamânının mihre-i mûsîkî-şinâsânından (Ramö) $^{12}$ zikrolunan usûllük hatâsını keşf ve muâhezât-ı şedîdeye ibtidâr etmekle Ruso'nun bu bâbda tashîh-i fikrine muvaffak olmuştur. Ma'mâfîh Ruso Paris'e vukû‘ bulan bu seyâhatinde meşâhîrden Fontenel ${ }^{13}$ Marivö $^{14}$ ve Didero $^{15}$ misüllü zevât ile ünsiyet peydâ eylediğinden dolayı istifâde eylemiştir. Bu avânda ma îşetince hâli gittikçe fenâlaşmakta idi. Binâen aleyh küberâ sınıfından kendisine dost geçinen bir Madam Fransa'nın Venedik sefâreti ma'iyyetinde bir me'mûriyet istihsâl etmiş ise de sefîrin sâ'ikâ-yı hubb-ı asâletle Ruso hakkında revâ gördüğü hakâret üzerine me'mûriyetini terk eylemiştir. [*] ${ }^{16}[9]$

Paris'de mûsîkacılık husûsunda tekrâr tecrübe-i muvaffakiyete kıyâm eylediyse de yine nâil-i merâm olamadığından tiyatrolara müdâvemete hitâm vermiş ve sülâle-i hükümdârîye mensûb olan mâlikânelerin nâzırı ma'iyyetinde bir hizmet kabûl etmiştir.

Müşârün-ileyhin 'ale't-tevâli tebeddül eden hevesâtı ve bu hevesât-ı mütebeddileden hâsıl olan heyecân-ı efkârı ile henüz işti'al etmeksizin intifâya başlamış olan fikr-i edebiyyâtını Dalamber ${ }^{17}$, Mabli, ve Didero'nun neşriyât-ı rûz-merresi tekrar 'alevlendirmeye sebeb olmuştur.

\footnotetext{
${ }^{8}$ Neuchatel: İsviçre'de bir şehir

${ }^{9}$ Chambéry: Fransa'da bulunan bir yerleşke

${ }^{10}$ Besançon: Fransa'da bir yerleşke

${ }^{11}$ Gabriel Bonnot de Mably (1709-1785): 18. Asrın önemli düşünür ve yazarlarından birisidir.

${ }^{12}$ Jean-Philippe Rameau (1683-1764): Fransız müzisyen

${ }^{13}$ Bernard le Bovier de Fontenelle (1657-1757): Fransız aydınlanmasında etkin bir rol oynayan ünlü Fransız düşünür

${ }^{14}$ Pierre Carlet de Chamblain de Marivaux (1688-1763): Fransız yazar

${ }^{15}$ Denis Diderot (1713-1784): Ünlü Fransız filozof

${ }^{16}\left[{ }^{*}\right]$ Ruso'nun bu bâbda mûma-ileyhâya yazdığı mektûb Sa'id Beg Efendi'nin [Fezâil-i Ahlâkiyye] 'unvânlı eserinin kısm-ı sâlisinde 'aynen muharrerdir. (Yazarın dipnotu)

${ }^{17} J$ ean le Rond D’Alembert (1717-1783): Ünlü Fransız matematikçi ve filozof.
}

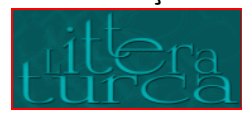

Journal of Turkish Language and Literature

Volume:5 Issue:3, Summer 2019, (471-487)

Doi Number: 10.20322/littera.530595 
Didero “A'mâlara Mektub [*]"18 'unvânıyla yazmış olduğu siyâsî bir eserden dolayı (Vensen) ${ }^{19}$ mahbesine atılmakla, Ruso dostunu tahlîs itmek içün elinden gelen gayreti sarf itmiş ve birçok def'alar Vensen hapishânesine giderek müşârün-ileyh ile mülâkât eylemiştir. İşte bu vazîfe-i dûstîyi îfâ eylediği esnâda ya'ni 1749 târîhinde "'ulûm ve sanâyi in terakkîsi [10] ahlâk-ı beşerin ıslâhına mı yoksa ifsâdına mı hizmet etmiştir?" su'âlini irâd eden ve i'tâ olunacak cevâb-ı muvâfıka mükâfât-ı nakdiyye va'd eyleyen (Dijon) encümen-i 'ulûmunun ${ }^{20}$ lâyihâsını mütâla'a ederken, o vakte kadar kendinde tahrîr ve te'lîfe kâbiliyet olduğundan haberdâr olmayan Ruso'nun fikrine bir kudret-i ma'rifet sânih olmakla, birinci def'a olarak bir makâle-i belîğâne tahrîr eyledi. [*] ${ }^{21}$ Bu mebhasda serdettiği mütâla'âtın netîcesinde eğerçi 'ulûm ve ma'ârifin ifsâd-ı ahlâk eylemesine hükm eyledi ise de makâlenin sûret-i tahrîrinde ittihâz ettiği üslûb-ı belâgat ve bast eylediği ma'lûmat ${ }^{22}$ ile başkalarının yazdığı makâlâta isbât-ı rüchân eylemesinden ta'yîn olunan mükâfât kendisine i'tâ olundu.

Gerek encümenin su'âli ve gerek Ruso'nun nutk yolunda kaleme aldığı makâle Volter'i fevka'l-gâye iğzâb etmişti. Çünkü Ruso nutkunda “üdebâya bir hadd ta yîn edeceğini” beyân etmiş olmasından o güne kadar nâm [11] ve şânı kimsenin ma'lûmu olmayan bir adamın bu derecelerde balâ-pervâz oluşuna karşı ne söyleyeceğini bile şaşırmış idi. Hatta Volter, o bâbda Didero'ya yazdığı bir mektûbda “bu serseri veya mecnûn herîf kim oluyormuş? Rivâyete göre vaktiyle sa'atçi çırâğı, ve sonraları da uşâklık etmiş bir Cenevre'li imiş. Bu serseri nasıl, ne maksatla ve ne 'akla hizmet ediyor da 'asırlarca tevâli eden tefekkürât ve ikdâmât-ı feylesofânenin vücûda getirdiği binâ-yı ma'ârif ve 'ulûmu tahrîbe cesâret idiyor? Bu sersemin haddini bildirmeye hiçbirinizin eli varmıyor mu? Bâ-husûs encümenin böyle bir suâl îrâd idişi 'ulûm ve ma'ârif nokta-i nazarında hezeyândan farklı bir şey midir?" demiştir.

Didero'nun Volter'e ne yolda cevâb verdiğini bilemeyiz. Fakat şurasını biliriz ki Jan Jak Ruso kendisine teveccüh eden şânlı bir istikbâle asla ehemmiyet vermeyerek ve her türlü esbâb-ı ihtişâmı pây-ı hakâretle basup geçerek fikr-i âzâdîsini takviyeden başka hiçbir şey [12] yapmıyor ve hatta biraz evvel girmiş olduğu çiftlik küttâbetinden dahi isti fâ ile "mûsîka notası mübeyyizi" olduğunu ve notaları "gâyet asah ve ehven sûretle istinsâh eylediğini" i'lân eyliyordu.

Müşârün-ileyh taharri-i hakîkatden başka bir fikre zâhib olmadığından, ne dîn nâmında bir tâkım ebâtîl ile halkı kuyûd-i müteselsile-i cehl ve a'mâya giriftâr eden ruhbâniyete ve ne de felsefe nâmına tağlîd-i zihn ve fikr eden vehmiyyâta tâbi' idi. Ruso'nun efkârınca nîce 'asırlardan beri kulûb-u nâssda kökleşmiş olan i'tikâdât-ı nasrâniye zulm ve 'adüvvânı tevlid eylemiş olduğu gibi felsefiyâtta gösterilecek şiddet dahi 'ayniyle o netîceyi hâsıl eyleyeceğinden vicdânını hiçbirinin yedd-i tahakkümüne teslîm etmek istemezdi. O vakte kadar gelen üdebâ

\footnotetext{
${ }^{18}\left[{ }^{*}\right]$ La lettre sur les aveugles a l'usage de ceux qui voient 1749. (Yazarın dipnotu)

${ }^{19}$ Vincenne

${ }^{20}$ Academie de Dijon: Dijon Akademisi

${ }^{21}\left[{ }^{*}\right]$ Makale-i mebhûsün- 'anhâ Sa'id Beg Efendi'nin kalem-i ma'rifetleriyle lisânımıza tercüme ve tab' û neşr idilmişdir. (Yazarın dipnotu)

${ }^{22}$ Metnin içerisinde "معلوت" olarak yazılmış olan bu kelime cümlenin akışına ve anlama göre tarafımızca malumat olarak okunmuştur.
}

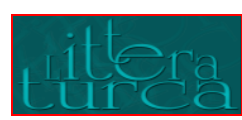

Journal of Turkish Language and Literature

Volume:5, Issue:3, Summer 2019, (471-487)

Doi Number: 10.20322/littera.530595 
kemâl-i cehd ile tecâvüzât-ı ruhbâniyeye bir sedd çekmeye muvaffak olduğu gibi Ruso dahi üdebâya bir hadd ta'yîni iddi'âsına kıyâm eylemiş idi. Ruso yazılan şeylerde şu'unât-ı kevniyenin vukû'u gibi, yani ifrât veya tefrît ile mâhiyyet-i asliyyesi değiştirilmeksizin ve hissiyât-ı kalbiyyeye müte'allik hâlâtın [13] dahi hakîkate muvâfık ve mübâlağâttan 'ârî bir sûrette tasvîr edilmesini tervîc etmek istiyordu. Çünkü müşârün-ileyhin ictihâdına göre 'akâid-i dîniyye dinilen ruhbâniyâta istinâden yazılan âsâr 'ukûl-i za'îfe erbâbını bir takım türrehâta i'tikâd ettirmekte ve felsefeye istinaden yazılan âsâr-ı 'ukûl-i zâ'îfe erbâbını bir takım türrehâta i'tikâd ettirmekte ve felsefeye istinâden neşr olunan şeyler dahi insânı, gavr ve hakîkatine vusûl yıllarca tetebbu'a mütevakıf bir takım 'ulûm ile iştigâle ve bu iştigâl ise zihn ve fikri işkâle düşürdüğünden her ikisi dahi netîce-i vâhideye müncer olmakta idi. Bu mütâla'âtın kâffesi (Dijon) encümeninin suâline cevâben irâd idilen nutukda, fakat mübhem bir sûrette zikrolunmuş olmasından ruhbân tâkımıyla cumhûr-ı felâsife arasında 'umûmi bir galeyân husûle getirmiş idi.

Bu esnâda ise Volter Prusya kralı Büyük Frederik'le ${ }^{23}$ bozuşarak Berlin'den 'avdet etmiş ve $\left(\right.$ Freney) ${ }^{24}$ kasabasında ihtiyâr-ı inzivâ eylemiş olmasından Ruso'nun neşriyâtına gayz ve gazabla karışık bir sekînet ile tahammül ediyordu. Yine bu esnâda idi ki Paris'in mûsîka encümeni tiyatroda "Köy Falcısı" nâmında bir fasıldan 'ibâret [14] küçük bir operayı mevki'-i temâşâya koymuş idi. Bu operacık iki genç kız ile bir ihtiyâr ve birkaç köylüden mürekkeb ve gâyet sâde birkaç şarkıyla müretteb idi. Şu kadar ve ona şarkılar muvâfık-ı tabî‘at olmakta o zamâna kadar neşr olunan bu gibi âsarın kâffesine isbât-ı rüchân eylemekte idi.

Alp dağlarındaki çobanların dağı bir makâm ve sâfi bir lisân ile şarkı söylemeleri ve onbeşer onaltışar yaşında iki kızın âvâze-i 'aşkı hem-ân âvâze-i vicdân diye hükm olunabilecek bir hâlisatla müsâmi'-i hüzzâra 'aks ettirmesi insânın kalbini teshîr ve pîş-nazarında fıtrat-ı evvelîyi tasvîr eyler idi.

Bu küçük operanın hâsıl ettiği te'sîr ta'bîr olunamaz bir hâlde idi. O vakte kadar hissiyât-ı beşeriyyeyi mübâlağâtı şâ‘irâne ile ta'rîf edenleri, bu iki kızcağız lisânından söylettirilen şarkılar bayâğı hâb-ı gafletten uyandırmağla cumhûr-ı üdebâyı bir inkılâb-ı velvele-bahşâ ile tebdîl-i tavır mecbûriyetinde bulundurdu.

Âyâ bu latîf temâşâ kimin mahsûl-i tasavvuru idi? [15] Gerek güftesi ve gerek bestesi kavâ‘id-i feylesofiyyeyi kuvvet-i fikr ve darb-ı nutk ile zîr û zeber eden ve Dijon encümen-i dânişinin mükâfâtına mazhar olan o, Cenevreli sâ'atçi çırâğı (yani oğlu) yâhûd uşâk bozuntusu, muhakkar ve hâne-berdûş olan Jan Jak Ruso nâm şahs-ı mechûl tarafından tertîb olunmuş idi. Binâen'aleyh müşârün-ileyhin nâmı Paris'de fevka'l'âde iştihâr bulmağla Ruso, üdebâ-yı 'asr içinde temeyyüze başladı. Hatta büyük pederinin yâd-i gâr seyyiâtı olup zamânında, bilâhare halefinin musîbetini intâc eyleyecek derecelerde ifrâta varan sefâhate hükümdârlık etmekte olan onbeşinci Lui ${ }^{25}$ bile bu operadan fevka'l-gâye zevk-yâb olmağla Ruso'ya onbin frank 'atıyye göndermiş ve fakat "buraya Kralın parası giremez" kavliyle Ruso tarafından redd olunduğu kendisine bildirilmesi

\footnotetext{
${ }^{23}$ II. Friedrich (1712-1786): Askerî ve siyasi başarılarından dolayı "Büyük" olarak anılmıştır

${ }^{24}$ Freney: Fransa sınırları içerisinde yer alan bir yerleşke

${ }^{25} \mathrm{XV}$. Louis (1710-1774): Fransa Kralı
} 
üzerine "yazık! Demek ki bu adamın müsâhabetinden ilelebed mahrûm olacağız" sözüyle kadir-şinâsâne izhâr-ı esef eylemiştir.

Falcı operasının te'sîrât-ı hâriku'l'adesi [16] henüz gönüllerde hükümfermâ iken Ruso, “Onsekizinci 'asrın lügâtü'l-fünûnu” ta 'bîriyle tercüme olunabilen ve Avrupaca dahi birinci def'a olmak üzere Didero ve Dalamber nâmında iki 'allâmenin teşebbüsüyle tertîb edilen [ansiklopedi] de "ekonomi-sosyal" "unvânı altında bir bend neşriyle mu'âsırlarına tekrar ilkâ-yı hayret eyledi.

Ruso mûsîkîye yeni bir usûl küşâd ettiği gibi bu makâlesiyle de müte'âmil olan usûl-i medeniyyeyi bir şekl-i âhire ifrâğ eylemiştir.

Volter bu şahs-ı garîbin neşriyâtını ve bâ-husûs zâtını herkesten ziyâde merâk etmekle ekser ahbabına yazdığı mektûblarda bu Jan Jak denilen kimse nasıl adamdır? Bir 'âkîl mi? Yoksa bir dîvâne mi? Suâl-i 'azamet iştimâlini vird-i makâl eylemiş idi.

Didero ise Ruso'nun meziyyât-ı fazl ve 'irfânını herkesten evvel ve herkesten ziyâde takdîr etmesinden müşârün-ileyh ile 'akd-i müvâhât eylediği gibi eserlerini de lügâtü'l-fünûna kabûl eylediğinden Volter'in bir 'azamet-i hod- [17] perestâne ile ikide bir de vâki' olan suâllerine cânı sıkılmağla, mûma-ileyh yazdığı bir mektûbda "şahs ve mahiyyetini suâl eylediğin Jan Jak Ruso 'asrımıza şeref verecek bir insân-ı kâmildir" cümle-i muhtasarasiyle hem müşârün-ileyhin meziyyâtını ta'rîf ve hem de zımnen Volter'in gurûruna ta'rîz eylemiştir.

Yine o sırada idi ki ansiklopedinin (J) harfi sırasında İsviçre'nin hükûmet merkezlerinden olan (Jenev) yani bizim ta'bîrimizce (Cenevre) lafzının ta'rîf ve tavzihi 'allâme-i 'asr Dalamber'in yedd-i ihtiyârına düşmüş ve bu hakîm-i sâhib-i kudret memleketin bedâyi'-i tabî'iye ve celâil-i sîyâsiyyesini mehâsîn-i müteferri'asıyla beraber hakkıyla ve tamamıyla tasvîr ettikten sonra, yalnız orada bir komedya tiyatrosu bulunmadığından dolayı müteessifâne bir ta'rîzcik îrâd eylemiş idi.

Bu makâle ansiklopedi eczâsında nazar-ı mütâla'sına eyleşmesi üzerine Ruso "Tiyatrolara Dâir Mektûb" 'unvânıyla ve müşârün-ileyh Dalamber'e cevâb olmak üzere vaktiyle terakkiyât-ı fünûn 'aleyhinde idâre eylediği efkâr [18] yolunda komedya tiyatrosunun da safvet ve selâmet-i ahlâkla muttasıf olan İsviçre'de lüzûmu olmadığına ve hatta muzırrâtı olduğuna müte'allik, yazılışca dünyanın en büyük eserlerinden ma'dûd olacak tarzda uzun bir mektûb neşr eylemiş ve bu eseriyle dahi 'âlem-i edebiyâtı yeniden velveleye vermiş idi. (Hatta Dalamber dahi istidlâlât-ı nazariyyece Ruso'nun mektûbuyla müsâvi dinecek derecelerde yazdığı cevâb-nâmeye) "hem uzun yazmak ve hem de yazdığını okutmak size mahsûs bir meziyyettir." cümle-i ihtirâmkârânesiyle bidâ eylemiştir.

Gerek Ruso'nun bu mektûbu ve gerek Dalamber'in cevâbnâmesi halkça yeniden bir istiğrâb husûlüne bâdî oldu. Çünkü Ruso kendi zâde-i tab'i olan Köy Falcısı’nın hüsn-i kabûle mazhar olduğunu bildiği hâlde yine tiyatroların 'aleyhinde bulunmuş ve Dalamber dahi cevâbında Ruso'nun irâd ettiği efkârın halkça hâsıl edebilmesi melhûz olan te'sîre meydân vermemek ve bununla beraber Ruso'yu dahi hiddetlendirip de teşyîd-i mütâla'atına sebep

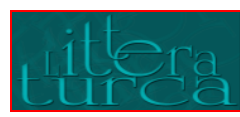

Journal of Turkish Language and Literature

Volume:5, Issue:3, Summer 2019, (471-487)

Doi Number: 10.20322/littera.530595 
vermiş olmamak içün gâyet hakîmâne [19] ve nezâhetkârâne bir üslûb ile def'-i i'tiraza çalışmış idi. Mâhasal Dalamber'in bu mektûbu Ruso'nun ne kıbâlde bir sâhib-i kudret olduğunu halka lâyık olduğu mertebelerde tefhîm etmiştir.

Hele yazdığı tiyatroların mazhar-ı rağbet olmasından dolayı böbürlenmekte bulunan Volter, Ruso'nun tiyatrolar mektûbunu okuduğu vakit hayret ve hiddetle memzûc bir hâlet peydâ eylemiş idi. Ruso'nun etvârı hakîkaten ebnâ-yı 'asrının hilâf-ı i'tiyâdı idi; zîrâ altıncı 'asırdan başlayıp sekizinci 'asra kadar terakkîdâr olan hikemiyât ve edebiyât dahi kendi 'âleminde bir nev' ifrât ve tefrît veyâ za'af ve şiddet nekâyısı ile ve bâ-husûs görenin me'âyıbıyla âlûde idi. Bu cihetle Ruso her ne yazarsa yeni diye kabûl olunur ve her neden bahs ederse hayretle görülür ve hele riyâkârâne bir tavr ile halka telkîn-i fezâil edenlerden olmaması kendisini bütün bütün garîb 'add ettirirdi. Çünkü her zamânda, her mekânda görülmüştür ki eğer i'tiyâd-ı nâssa muhâlif ise hakîkat-perdâzlık dahi garâibden ma'dûd olur. [20]

Dijon nutkundan daha mükemmel olan tiyatro mektûbunun intişârını müte âkîb garîb- ender-garîb 'addolunacak bir şâyî‘a daha deverâna başladı: O da ekser âsârında o vakte kadar romanları derece-i nihâyede tezyîf ile erbâbına nefrîn-hân olan Jan Jak Ruso'nun "'aşk” üzerine bir roman yazmış olduğu haberi idi. Hele en garîbi zikrolunan hikâyenin matbû' olmaması idi. Jan Jak Ruso fevka'l'âde vasıfla edâ idilebilecek derecelerde bir hüsn-i hatta ve hüsn-i hat ile beraber sür'at-i istinsâha mâlik olmasından romanının neshini teksîr etmekle hemân ağırlığınca altûna olmak üzere nisvân-ı ekâbîre fürûht eylerdi.

Bu kitâbı mütâla'a eden nisvânın 'ale'l-'umûm kalblerinden 'alâmet-i tesîr olarak bir âh-ı cân-güdâz kopmaması nâ-kâbil idi. Çünkü fahş ve rezâletin mertebe-i kusvâya vâsıl olmuş olduğu bir 'asırda kadınlara fezâil-i muhabbet ve 'aşk-ı hakîki ne demek olduğunu bu kitâb telkîn eylemiş idi. Eser o kadar muharrik-i sevdâ ve o rütbe câlib-i iştihâ bir tarzda yazılmış idi ki her okuyan kadını [21] mukâvemeti nâ-kâbil bir lerze-i 'aşk istîlâ eylerdi. Bu hikâyenin nâmı ise (Noel Eloiz) ${ }^{26}$ idi.

Bu roman intişâr eylediği ve mündericâtına dâir rivâyetler deverâna başladığı zamân herkes Ruso'nun tebdîl-i meslek eylediğine zâhib olmuş idi. Fakat hikâyeyi bizzât ele alanlar Ruso tarafından kitâbın mukaddimesi makâmındaki hasbihâli okur okumaz yeni bir garîbeye daha ıttıla ile düçâr-ı veleh olmakta idiler. Çünkü Ruso hasbihâlinde üdebâya olan muvâhezâtında devâm ile berâber hikâye kitâbları hakkında i'tirâzât-ı şedîdede bulunuyordu, ki o mukaddime-i garîbenin ibtidâsından birkaç satırını numûne olarak burada irâe edebiliriz.

“Büyük şehirler tiyatrolara ve fesâd-ı ahlâka mübtelâ olmuş akvâm-ı hikâye kitâblarına muhtâç bulunuyorlar. Ben zamânımın ahlâkını gördüm de bu mektûbları neşr eyledim. Kâşki bu mektûbları âteşe atmağa mecbûr bulunacağım bir 'asırda yaşamış olsa idim."

\footnotetext{
${ }^{26}$ Julie ou la Nouvelle Héloise: Rousseau tarafından neşredilmiş mektup-roman tarzında yazılmış bir eser

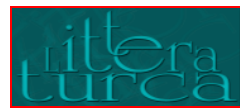

Journal of Turkish Language and Literature

Volume:5 Issue:3, Summer 2019, (471-487)

Doi Number: 10.20322/littera.530595
} 
"Vâkı'an kitâbın üzerinde yalnız nâşiri olduğum muharrer ise de kitâbın muharriri de ben olduğumu âslâ ihfâ etmek istemem. Yazılanların hepsini ben mi yaptım. Yoksa muhâberât [22] 'umûmen düzme şeylerden mi 'ibârettir; buraları nenize lâzım! Sizin içün bunlar mutlakâ tasnî‘âtdan ma 'dûd olmalıdır."

“Her nâmuslu adam neşr ettiği eserin mü’ellifi kendisi olduğunu i'tirâf ve i'lân ile mükelleftir. Binâen'aleyh kendime mâl etmek maksadıyla olmayarak, mahzan vâki olacak i'tirâzâta cevâb vermek içün ben de bu kitâbın üzerinde nâmımı i'lân ediyorum..."

Bu hikâyeden sonra zikr olunan Dijon encümeni “beyne'l-beşer 'adem-i müsâvâtın sebeb-i aslîsi nedir?” diye bir mesele daha i'lân etmekle Ruso ana dâir pek güzel ve gâyet mufassal bir makâle yazdı ise de o vakitler Fransa'da câri olan hükûmet-i keyfiyye 'aleyhine hayli dik sözler söylemiş olduğundan mev'ûd olan mükâfâta sezâvâr görülmedi.

1759 senesinde [Kontra sosyal] ${ }^{27}$ ya'ni şerâit-i ictimâ' 'unvânıyla bir kitâb neşr ederek, heyet-i ictimâ'iyeyi bir kâ‘ide-i tabi iye üzere teşkîl etmeyi tavsiye ve beyne’n-nâss müsâvât-ı mutlâkayı esâs-ı ictimâ‘ olarak irâe eyledi.

Bu kitâb eyâdî-i erbâb-ı siyâsette dolaşmakta iken [23] terbiye-i etfâle dâir [Emil] ${ }^{28}$ nâm şâkird-i mefrûza hitâb sûretinde yazılmış bir kitâb daha te'lîf eyledi. [*] ${ }^{29}$

Bu eserler öyle şatahat-ı edebiye ve yâhûd türrehât-ı şâ'irâne kabîlinden olmayıp ebnâ-yı beşerin ve ta'bîr-i ehassla heyet-i medeniyyenin esâs ve vezâifine müte'allik mesâil-i 'âleyh ve dakîkadan ve o zamana kadar emsâli görülmemiş mü'ellifâttan bulunduğundan Avrupa'nın her tarafında mazhar-ı kabûl-i 'âmme oldular. Hatta bu eserler üzerine Ruso'nun şöhret-i iktidârı o zamana kadar dillerde dâsitân olan Volter'e bile rekâbet eyledi.

Ruso [Emil]de ekânîm-i selaseyi berâhîn-i 'akliyye ile red ve vahdâniyet-i ilahiyyeyi isbât eylediğinden ruhbân takımı müşârün-ileyhin rafz ve ilhâdına hükm ile beraber hapsine irâde çıkardılar.

Bu iki kitâb hakîkaten o 'asra göre yalnız 'avâm-ı nâss içün değil, havvâs-ı hükemâ içün dahi i'tiyâdın [24] mâfevkinde telakkî olunduğundan mu'asırları bulunan üdebâ-yı hükemâ hayretten istiğrâba, istiğrâbdan hiddete, hiddetten gazaba düçâr olmuşlar idi.

Bunlar hayret ve gazablarını henüz teskîn etmeden Ruso "Savoalı Râhib" ve "Paris Baş Papazına Mektûb" nâmındaki eserleri neşr eylediğinden yukarıda etvârını ta'rîf eylediğimiz zevât hayret ve istiğrâblarını bir kat daha artırdılar. Hatta Volter kemâl-i hayretle: Âh! Bu mecnûn, bir refîk-i sâhte olmamış olsa idi. Kendisini ne kadar sevecek idik" demeye mecbûr olmuş idi. Muahharan Ruso'nun "Savoalı Rahibin va'azı” nâmıyla şerâit-i ictimâ'iyye ve Emil kitâblarının ba'zı mebâhisini izâh yolunda neşr eylediği bir risâle Volter'in nazar-ı

\footnotetext{
${ }^{27}$ Du contrat social ou Principes du droit politique: Toplum Sözleşmesi

${ }^{28}$ Émile ou de l'éducation: Emile ya da Eğitim Üzerine

${ }^{29}\left[{ }^{*}\right]$ İşbu Emil kitâbını Ziyâ Pâşâ merhûm Türkçemize tercüme eylediği gibi ba'zı havâşi-i münâsîbe 'ilâvesiyle mesâil-i gâmizasını şerh eylemiştir. (Yazarın dipnotu)
}

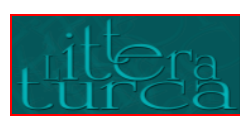

Journal of Turkish Language and Literature

Volume:5, Issue:3, Summer 2019, (471-487)

Doi Number: 10.20322/littera.530595 
mütâla'asından geçtiğinden müşârün-ileyh dahi kendine mahsûs bir lisân ile ahbâbına ekseriyâ şu sözü söylemekten geri durmamıştır: [25]

“Ruso mecnûndur; hiç şübhe etmem. Ma'mâfîh Savoalı Rahib’i tasvîr eden de o mecnûndur. Bu eseri size tavsiye ederim. Okuyunuz; 'âleme neşrediniz! Ve ihtivâ ettiği nesâyih-i 'âkilâneden istifâde ediniz! Ben o kitâbı altûnla ciltlettim."

Ruso mü ellifâtında dâimâ tabî’at tarafını iltizâm ile terakkiyât-ı medeniyye nâmı verilen etvâr-ı zamânenin ve zamânındaki feylesofların hilâfında bulunmağla hem erbâb-ı hükûmet hem rehâbîn ve hem de erbâb-ı felsefe kendisine izhâr-ı gayz ve kîn ederler idi. Bu üç sınıfı birden 'aleyhine kışkırtmak ne kadar büyük bir eser-i cesârettir.

Papazları iğzâb etmek o zamânın tavr-ı ta'assubu hükmünce 'âmme-i nâssı iğzâb etmek demek iken Ruso, hakîkat-perdâzlıktaki i'tiyâdını muhâfazadan başka bir şey düşünmemiştir.

Ruso, kendisi içün sâdır olan i'lâm-ı nekâli istihbâr eder etmez hatt-ı destiyle muharrer ve imzâsını hâvî olan "Paris Baş Rahibine Mektûb” "unvânlı risâlesini [Noterdam dö Pari] ${ }^{30}$ kilisenin mazbahına, ya'nî mahfel-i mukaddesine kendi eliyle bıraktıktan sonra, başına o zamânın İstanbul Ermenîlerine mahsûs olan kalpağı ve sırtına uzun entarî ile cübbe ve ayağına çakşır ve mest papuş giyerek Paris'den İsviçre'ye firâr eyledi. [26]

İktisâ etmiş olduğu kisve-i müste âr ile mütenekkiren biraz müddet geşt û güzâr eylemiş ise de eserlerini katolik kilisesi tarafından sâdır olan fermân mütehattimü'l-imtisâl üzerine cellâd eliyle Cenevre' de 'ala melâin-nâs ihrâk olunduğunu bi't-tesâdüf reyü'l-'ayn müşâhade etmesi ve bâ-husûs tutulup hapsedilmesi hakkında dahi emr sâdır olduğunu istimâc eylemesi üzerine (Nöşatel) Prensliği dâhiline ilticâ eyledi.

İşte Ruso, Piskoposluk tarafından vârid olan celb-nâmeye olan cevâbını ve (Mektûbât-ı Cibilliye) 'unvânlı risâlesini o vakit yazmıştır.

Cenevre hükûmetinin, 'aleyhindeki teşebbüsât-ı 'adâvetkârânesinden kurtulmak içün (Biyen)' gölünün ortasında kendisine melce ittihâz eylediği (Sen-Piyer) ${ }^{32}$ cezîre-i sagîresinde tûl müddet ikâmetten usanmağla Ingiltere'ye 'azîmet eyledi. İngiltere'de meşâhîr mü'verrihinden (Hum) 33 nâm zât kendisine 'arz-ı himâye ederek müşârün-ileyhi (Derbi) ${ }^{34}$ kontluğu dâhilinde bir mahalde iskân eylemiş idi. Fakat meftûn-ı hakîkat olan [27] ve bu sebeple ekser husûsatda kendisini hiddete sevk eyleyen tabî‘atı [Hum] ile bozuşmaklığını intâc eylemesi üzerine Ruso, İngiltere'yi terk ile Fransa'ya 'avdet eyledi. Müşârün-ileyhi bu 'avdetinde halk ve yalnız halk değil ekser havâss alkışlar ile istikbâl eylediler. Çünkü müddet-i gaybûbetinde neşrettiği mektûbâtıyla ruhbâniyetin ledünniyât-ı şeytânetkârânesini havâs ve 'avâm nazarında isbât ettiği gibi kendisinin mütekavvil bir feylesof

\footnotetext{
${ }^{30}$ Notre-Dame de Paris: Fransa'nın Paris şehrinde bulunan bir katedral

${ }^{31}$ Lac de Bienne: İsviçre'de bir göl

${ }^{32}$ Saint-Pierre: Fransa'da bir yerleşke

${ }^{33}$ David Hume (1711-1776): Filozof, tarihçi

${ }^{34}$ Derby: İngiltere'ye bağlı bir kontluk
} 
olmayup ef'âliyle dahi mehâsin-i ahlâka mâlik bulunduğunu ve ebnâ-yı beşerin sa'âdeti nâmına mevzû' olan kavâ‘id ve usûlü iğrâz-ı mahsûsaları yolunda isti'mâl edenlere kâlen ve kalemen i'lân-ı harbden hazer etmediğini göstermiş idi. Binâen'aleyh papazların sademât-ı kâhirânesine mukâvemet etmekle beraber halkı mukteziyât-ı hilkâtinden haberdâr etmek yolunda hiçbir şeyden pervâ etmemesi halkın teşhîz-i zihn ile beraber kendisini taltîf etmesini intâc eylemişti. Ricâl-i 'asırdan Prens Konti ${ }^{35}$ bu “avdetinde müşârün-ileyh (Tri-le-şato) ${ }^{36}$ da [28] bir melce ta'yîn etmiş ve iki ay kadar orada misâfir etmeğe muvaffak olmuştur. Bu târîhden sonra Ruso birbirini müte âkib Lyon, Grenöbl ${ }^{37}$, Şambri, ve Burugan ${ }^{38}$ şehirlerine 'azîmet ve Burugan'dan ve tekrar Lyon'a ve andan sonra Paris'e 'avdet eylemiştir. Ruso'nun insanlara olan nefreti günden güne tezâyüd etmekte idi. Her ne söylenirse riyâ, her ne yapılırsa halkı iğfâl maksadıyla yapılmakta olduğuna tamamıyla kanâ'at hâsıl etmiş olduğundan esere de, mü'essire de yâhûd iğfâl edenlere de iğfâl olunanlara da nazar-ı nefretle bakmağa başlamış idi. Binâen'aleyh herkesle ihtilâtını kat' eyledi. Ve hatta yazı yazmamağa kati'yyen 'azm eylemekle onda hokka, kâğıt ve kalem gibi vesâ'it-i kitâbeti kâmilen def' ettirdi. Fakat bu hâle pek çok zamân tahammül edemeyerek nihâyet günün birinde fevka'l-gâye heyecâna gelen efkârına mağlûb olmağla çekilmiş olduğu köyün tahsîldârından bir hokka getirterek "Konfesyon dö Föva" ya'nî bizim 'âdât ve ıstılâhâtımıza göre (nâme-i a'mâl) lafzıyla tercümesi kâbil olan eser-i bînazîrini vücûda [29] getirdi. Ruso bu kitâbında mücerred her hâli hakkı üzere beyân maksadıyla hırsızlığa varıncaya kadar irtikâb eylediği ve yâhûd etmek istediği kâffe-i kabâyihini meydâna koymuş ve hatta mukaddimesinde divân-ı mahşere varup da a'mâline dâ'ir bir hitâb-ı 'izzete mazhar olunca cevâben o kitâbını 'arz etmek isteyeceğini beyân etmiştir.

Ruso zâten 'uzemâ ve ekâbîr ile ülfet ve ihtilâttan ibâ eyleye geldiği hâlde şöhret-i fevka'l'adesine binâen herkes kendisiyle ülfete vesîle-cû idi. Binâen'aleyh ashâb-ı merâtib veyâ haysiyetle kendi beynine, aşılması muhâl bir sedd çekmek içün köylü bir kız ile 'akd-i izdivâc eyledi. Ruso (Köy Falcısı) ve (Eloiz) ve (Emil) nâmındaki âsârıyla zamânındaki nisvânın kulûbunu teshîr eylemiş olduğundan istemiş olsa idi bir düşes ile izdivâc eyleyebilirdi.

Müşârün-ileyh izdivâcından sonra kıyâfetini tebdîl ederek gûşe-i tenhâyîye çekilmeği tercih eyledi. Ahâd-ı nâssdan bir kızla tezevvüc eylediği Paris'de şâyi olunca [30] herkes Ruso'nun cinnetine hükm eylemiştir. Fakat bilâhare müşârün-ileyhin ma'îşet-i inzivâ-perestânesi pîş-i nazara alınmağla o hükümdeki hatâlarını i'tirâf ile tashîh eylediler. Ma'mâfîh istiğrâb-ı 'âmmeye bâ'is olan hâl yalnız izdivâc husûsu olmayıp çünkü Paris piskoposuna yazdığı mektûbuyla katolik ve protestan kiliseleriyle kat'-i münâsabât ve binâen'aleyh mûvahhidliğini i'lân eylemiş olmasından ve o zamân (nikâh-ı medenî) dahî müte’arif olmamasından Ruso'nun ‘akd-i nikâh içün ne tarîka sülûk edeceğini 'umûmen Paris halkı neseb-i ‘ayn eylemiş idi.

\footnotetext{
${ }^{35}$ Prince de Conti: Branche cadette de la maison de Condé, elle-même issue de la maison de Bourbon. Formée en 1558, la maison de Conti disparut en 1614, se reforma en 1629 et s'éteignit en 1814. https://www.larousse.fr/encyclopedie/groupe-personnage/maison_de_Conti/114548 (Erişim Tarihi: 24.04.2019)

${ }^{36}$ Trie-Château: Fransa' da bir yerleşke

${ }^{37}$ Grenoble: Fransa'da bir yerleşke

${ }^{38}$ Bourgoin-Jallieu: Fransa'da bir yerleşke
} 
Meslek değiştirmeği gömlek değiştirmek kadar sehl 'add edenler, Ruso'nun istiğfâr-ı zünûb ile kiliseye mürâca'at eyleyeceğini za'm ederler idi.

Vâkı'an o 'asrın kânûnu hükmünce bir adam bir kiliseye mürâca'ât edip de nikâhını âyîn-i 'i̇sevî üzere 'akd ettirmezse halk zevcesini (kapatma) hükmünde telakkî eyler idi. Ruso ise kiliseden matrûd ve ta'bîr-i âhirle ebâtîl-i ruhbâniyye 'indlerinde merdûd olanlara ahkâm-ı 'adâletin bîgâne olamayacağını isbât içün i'tikâd-ı [31] 'âmmeye asla 'itibâr etmeyerek 'akd edeceği (Terez Levaser) ${ }^{39} \mathrm{i}$ iki şâhidin huzûruna ikâme ile kendisini zevceliğe kabûl ettiğine dâ'ir kasem eylediği gibi kız dahî Ruso'yu zevc edindiğini kasemle ikrâr eylediğinden nikâh-ı ehl-i İslâm gibi izdivâcları ini'kâd eyledi, ki Ruso bu hareket-i cür'etkârânesiyle mu'ahharan Avrupa'da zuhûr eden ve el-yevm ekseriyet 'indinde düstûrü'l-'amel olan (Marya Jesyol) yani nikâh-ı medeniyye vaz'-ı esâs eylemiş oldu.

Müşârün-ileyhin sûret-i izdivâcı şâyi` olunca Ruso'yu rafz ve ilhâd ile zemm û takbîhe başladılar ise de nev'-i beşer i'tiyâdına mugâyir olan hâlât hakkında vehleten mûahezât-ı şedîdeye mübâderet eylediği hâlde yavaş yavaş o hâlet-i mugâyire ile dahî kesb-i ülfet ederek bilâhare anın hilâfına muấrız olmağa mükibb olmasından, Ruso'nun şekl-i izdivâcı dahî gitgide ehemmiyetini zâyi' ederek elsine-i nâsdan sâkıt olmuştur.

Terez, Ruso ile bir müddet hoş geçindikten sonra [32] 'asrının ahvâl-i meş'ûmesinden olarak, bir bağçevân ile mu'âmele-i âşüftegîde bulunmağla gerek Ruso'nun ve gerek kendisinin insilâb-ı huzûr ve âsâyişine sebeb olmuştur.

Terez'in en büyük hatâsı ve belki 'afv olunmaz kabâhati Ruso, çocukları etfâl-i multakataya mahsûs olan beyt-i sıbyâna götürdüğü zamân buna muhâlif etmemesi idi.

Ruso bu musîbetten sonra dünyadan büsbütün nefret ederek Paris'den uzak bir karyeye çekilmiştir. Kendisinin nerede olduğunu bilip de ötekinin birinin gelip ta'cîz etmemesi içün ismini dahî Mösyö (Renö)ye tebdîl eyledi.

Tahrîr-i âsârdan bi'l-külliye fâriğ olmağla ne kadar kitâbı varsa cümlesini satmış ve fakat kırda dolaştıkça medâr-ı tetebbu've iştigâl olmak üzere nebâtâta dâ‘ir birkaç kitâb iştirâ eylemişdir.

İşte bundan sonra kâh kırda gezerek eydî-yi beşerden masûn kalan âsâr-ı tabî́iye-i gird-gârı temâşâ eder ve kâh evde kalarak mûsîka ile imrâr-ı evkât eyler idi.

Ruso her şeyi terk eylediği hâlde zevcesine olan fart-ı muhabbetinden mûmaileyhâyı terk edememiş [33] ve Terez ise ettiği hatâya ilelebed izhâr-ı nedâmetle son dakîka-yı hayâtına kadar Ruso ile hüsn-i âmîziş eylemiştir.

Kendisine perestiş eden ba'zı zevât müşârün-ileyhin nâm-ı müste'ârını ve ikâmet eylediği mahalli öğrenerek Ruso'yu ziyârete gitmişler idi. İçeri girdikleri zamân müşârün-ileyhi zevcesiyle birlikte yemek pişirmekle meşgûl bulmalarıyla fevka'l-gâye ta'accüb eylediler. Böyle neşriyât-ı hâriku'l'âdesiyle Avrupa'ya velvele-endâz iştihâr olan bir sâhib-i kemâlin 'âdî adamlar gibi yemeğini pişirmekle meşgûl oluşunu garîb gördüler. Çünkü anlar büyüklüğü dört atlı 'arabalarda ve evânî-i sîm û zer ile ârâsta ve kadîfe esvâblı, beyâz boyun bağlı uşâklarla

\footnotetext{
${ }^{39}$ Marie-Therese Levasseur (1721-1801): Rousseau'nun eşi

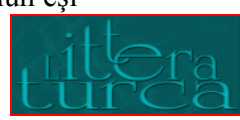

Journal of Turkish Language and Literature

Volume:5 Issue:3, Summer 2019, (471-487)

Doi Number: 10.20322/littera.530595
} 
muhât sofralarda bulmağa alışmış zevâttan idiler. Hatta o 'azametli Volter bile ihtişâm-fürûşlukta ekâbir-i 'asrıyla atbaşı beraber bulunmağı i'tiyâd etmiş idi.

Ruso ise eğer canı isterse ufak bir nevâle torbasını dûş-i tahammülüne attığı gibi mâşiyen vatanı olan Cenevre'ye 'azîmet ve yine o sûretle Fransa'ya 'avdet ederdi. Ma'mâfîh böyle yaya olarak kırk elli [34] fersah mesâfe kat' eden ve senevî sekiz yüz franktan 'ibâret vâridatıyla köyde ta'ayyüş eden bu adamın tercümân-ı efkârı olan kaleminden südûr eden her kelimeden "Roma'daki papa (Freney)deki Volter ve büyük Frederik müstesnâ olarak" 'umûm Avrupa hükümdârânıyla cumhur-ı 'ulemâ bir nev' endişeye giriftâr olurlar idi.

Ruso, âhir-i 'ömründe Fransa'nın (Ovaz) ${ }^{40}$ eyâleti dâhilinde (Ermenoil) ${ }^{41}$ kasabasında Kont Dujiraden tarafından kendisine ihdâ olunan sayfiyye-i 'âliyyede imrâr-ı evkât ederek 1778 sene-i milâdiyesi hazîrânının ikinci günü vefât etmiştir. Na'aşını vasiyeti üzerine kasaba-yı mezkûr sâhasındaki gölün orta yerinde bulunan cezîre-i sagîreye defnetmişlerdir. Fakat 16 sene sonra, ya'nî Fransa inkılâb-ı 'azîminin en dehşetli devri olan sene-i evvelîsinde 'uzâm-ı bedeni mezârından kaldırılarak medfen-i e'âlî ittihâz edilen (Panteon) ${ }^{42}$ nâm binâ-yı 'alîye nakl ile vaz'-ı mevki'-i ihtirâm edilmiştir.

Ruso'nun avân-ı hayâtı işte bu sûretle güzerân eyledi. Müşârün-ileyhin kalbi rikkat-âlûd bir nezâket ve efrâd-ı [35] beşer hakkında gâyet vâsi' bir muhabbet ile memlû idi. Mertebe-i mefratada bir kuvve-i muhayyile kendisini tavr-ı zamânın fevkine çıkarır ve ebnâ-yı 'asrına göre hayâl ve belki 'ayn-ı vebâl 'addolunacak sûrette serd-i efkârda bulundururdu. Zekâsı fevka'l-âde olup fazîlete, hakîkat ve 'adâlete ve hüsn-i etvâr ve ahlâka 'âdetâ 'âşık idi. Binâen'aleyh bu hasâ'il-i 'âliyyenin kavâ'idini kemâl-i belâgatle müdâfa'a eylemiştir.

Müddet-i ‘ömründe kimseye tabasbus ve tenezzül etmemiş ve kimsenin bâr-ı minneti altında bulunmamıştır. Fakrı ile fahr eyler ve musâhibetine hâhişger olan küberâ-yı 'asra ahâd-ı nâss gibi mu'âmele edip hediye ve 'atıyyelerini redd eyler idi.

Hele Ruso her şeyden evvel Hristiyan olmayıp muvahhiddir. Ana ise balâda beyân eylediğimiz (Savoalı Râhib) lisânından naklen yazmış olduğu ikrâr-ı din bahsi şâhittir.

Temme

$*$

Matba'a-i Ebûzziyâ [36]

\footnotetext{
${ }^{40}$ Oise: Fransa'da bir bölge adı

${ }^{41}$ Ermenonville: Fransa'nın Oise bölgesine bağlı bir yerleşke

${ }^{42}$ Panthéon de Paris: Fransa'nın Paris şehrinde bulunan yapı. Bu yapıda Voltaire, Rousseau gibi birçok önemli ismin naaşları buradadır.
}

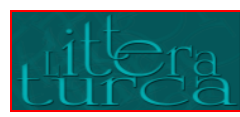

Journal of Turkish Language and Literature

Volume:5, Issue:3, Summer 2019, (471-487)

Doi Number: 10.20322/littera.530595 


\section{SONUÇ}

Tanzimat Devrindeki en önemli olgulardan birisi tercüme faaliyetleridir. Bu dönemde birçok Osmanlı münevveri gerek Batı Medeniyetinin gerek Doğu Medeniyetinin kilometre taşlarını Türkçeye kazandırmış ve bu faaliyetlerle Türk aydınlanmasının yol haritasını çizmişlerdir.

Tercüme ettikleri birçok isim hakkında tercüme-i haller yazan Tanzimat münevverleri bu isimlerin tanınmasına ön ayak olmuşlardır. Nitekim tercüme-i hâl yazımının önemli isimlerinden biri olan Ebüzziya Tevfik de bahsi geçen Batı ve Doğu Medeniyetlerine ait isimlerin toplum tarafından tanınmasında büyük rol oynamıştır.

Bu çalışmamızda, Tevfik'in ünlü Fransız düşünür Jean Jacques Rousseau'nun tercüme-i hâlini Latin harflerine aktardık. Böylelikle dönem münevverinin başka sanatçı ve düşünürlere bakışını anlamanın önemini vurgularken diğer taraftan kültürümüze ait eserlerin tanınmasının ve anlaşılmasının gerekliliği sonucuna vardık.

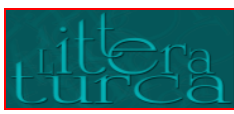

Journal of Turkish Language and Literature

Volume:5 Issue:3, Summer 2019, (471-487)

Doi Number: 10.20322/littera.530595 


\section{KAYNAKÇA}

Ebüzziya, Ziyad (1994). “Ebüzziyâ Mehmed Tevfik”, İslam Ansiklopedisi, C. 10. İstanbul: Türkiye Diyanet Vakfı Yay. 374-378.

Orhan, Özgüç (2013). "Rousseau ve Türkiye", FLSF (Felsefe ve Sosyal Bilimler Dergisi), 2013 Güz, sayı:16, s.121148 ISSN 1306-9535.

Perin, Cevdet (1946). Tanzimat Edebiyatında Fransız Tesiri. İstanbul: Pulhan Matbaası.

Rousseau, Jean Jacques (1991). İtiraflar I, (Çev: R. N. Güntekin). İstanbul: Milli Eğitim Basımevi.

Simavi, Sedat (1931). Jan Jak Ruso (Jean Jacques Rousseau) Hayatı-Eserleri. İstanbul: Kanaat Kütüphanesi.

\section{E-Kaynaklar}

https://www.larousse.fr/encyclopedie/groupe-personnage/maison_de_Conti/114548

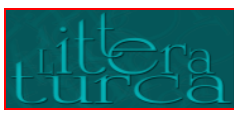

Journal of Turkish Language and Literature

Volume:5, Issue:3, Summer 2019, (471-487)

Doi Number: 10.20322/littera.530595 